\title{
Market Orientation, Innovation and Its Impact on Environmental Sustainability Practices: Evidence from Indonesian Palm Oil Companies
}

\author{
R N Sari ${ }^{1 *}$, D Junita ${ }^{1}$, R Anugerah ${ }^{1}$, Yusralaini ${ }^{1}$ \\ ${ }^{1}$ Department of Accounting, Faculty of Economics and Business, Universitas Riau, Kampus Bina Widya, \\ Km. 12.5 Simpang Baru, Panam, Pekanbaru, 28293, Indonesia \\ *ria.nellysari@lecturer.unri.ac.id
}

\begin{abstract}
This study aims to examine the effect of market orientation o innov tion and then its impact on environmental sustainability practices. Data was ob ined through questionnaires distributed to 178 respondents who were the top ar 1 middle anagers of the palm company. Data then analyzed by SEM-PLS anal sis echniques through WarpPLS 5.0. Results showed that market orientation has a ign icant effect on innovation and environmental sustainability practices further aralysis found that innovation mediates the relationship between marke on ntation and environmental sustainability practices. This study suggests that environmen 1 sustainability practices are important to ensure the sustainability of Palm J11 Company.
\end{abstract}

Keywords: Market orientation, innovation, enviro me tal sustainability practices, palm company, Indonesia

\section{Introduction}

Environmental sustainability is a topic of international discussion in the context of sustainability develop ent, a concept that directs the need to adjust goals that pay attention to economic developn ant, environmental and social protection. Bruntland Commission (formerly: World Con $\eta$ sion on Environment and Development) since 1983 has been building awar nes s of the importance of sustainability development. Consumer awareness of sustainability ases customer demand to place more emphasis on products and services that are environmen. lly friendly and are produced through processes that do not damage the environment [1].

Customers place their primary concern on sustainability, which requires market-oriented organizations to also make sustainability a major focus in determining their business strategies [2]. Market orientation is the activity of collecting and using market information and focusing the coordination of resources to provide superior customer value [3].

Market-oriented companies will better serve their customers based on market information [4]. Based on resource-advantage theory, market oriented companies will have a competitive advantage compared to companies that are not market-oriented. Furthermore, market-oriented companies recognize that demands and needs for environmentally friendly products, then encourage organizations to make efforts to preserve the environment. Market-oriented companies will quickly identify changes in customer demand and implement them in environmental sustainability practices [5]. 